religious garb in the public schools even when no statute is present-particularly in view of the fact that the hardship on the religious may be negligible. ${ }^{41}$

"Modification of garb to fit necessity is recognized by the Catholic Church. Codex Juris Canonici, Canon 136, $\$ 1$ : "All clerics should wear a becoming ecclesiastical dress, according to the legitimate local customs and the prescriptions of the ordinary [bishop] of the place." Canon 596: "Religious must wear the proper habit of their own religious group both indoors and outdoors unless some grave cause excuses and this is to be decided by the superior."

\title{
SHAREHOLDERS' LIABILITY FOR SALE OF CONTROLLING INTEREST
}

The right of a controlling shareholder to dispose of his interest in a corporation is subject to few restrictions. Perlman v. Feldmann, ${ }^{1}$ recently decided by the Court of Appeals for the Second Circuit, raises the possibility that these restrictions may be greatly extended. This comment will examine that case to determine whether it departs significantly from prior law, or can be reconciled within the existing framework of cases.

\section{I}

For some time prior to 1950 steel had been in short supply, and producers were able to command a high price for their product. Industry ethics, however, frowned upon raising mill list prices, although this was not illegal, and it was customary for small producers to take advantage of the favorable market situation by indirectly raising their prices. Newport Steel Corporation sold its steel at the standard mill list price, but required that the purchaser make an interest-free advance of the purchase price long before delivery. ${ }^{2}$ The real price charged by Newport, therefore, consisted of the amount of the mill list price plus a "premium," the value of the use of the money advanced by the purchaser. The steel shortage was aggravated by the Korean War in $1950 .^{3}$

In August 1950, Feldmann, Newport's controlling shareholder, ${ }^{4}$ sold his

${ }^{2} 219$ F. 2 d 173 (C.A. 2d, 1955).

" "Between 1946 and 1947 Newport entered into separate contracts with seven large steel users by which, in consideration for commitments to deliver specified quantities of steel from its existing facilities, the customers "advanced" an aggregate of $\$ 3,510,000$ without interest, to be treated as $10 \%$ of the price of steel thereafter to be delivered over a 36-months' period." Brief for Appellant at 14, Perlman v. Feldmann, 219 F. 2d 173 (C.A. 2d, 1955). "During 1948-1949 Newport raised $\$ 10,000,000$ from customers to buy additional facilities. ..." Ibid.

${ }^{3}$ Certain sellers were able to obtain up to $100 \%$ or more above the mill list prices. Wall Street Journal, p. 3 , col. 3 (July 27,1950 ).

-Thirty-seven per cent of the shares constituted control in this instance. The controlling shares were owned by Feldmann and members of his family. Those members were joined with Feldmann as defendants in the suit and the judgment finally rendered was directed against them as well as Feldmann. However, because Feldmann took the 
stock to Wilport Company, a syndicate of steel consumers anxious to secure a source of supply. ${ }^{5}$ Feldmann received for his stock twenty dollars per share, at a time when it was selling in the market for approximately eleven. ${ }^{6}$ At the time of the sale Feldmann was aware of the character of Wilport and of its reason for purchasing his stock. ${ }^{7}$ Once in control of Newport, the parent Wilport allocated all of the new subsidiary's uncommitted output to itself, but paid only the mill list price, depriving Newport of the premium which it had been receiving.

The minority shareholders 8 brought a derivative action in which they sought to force Feldmann to share with them part of the proceeds from his sale of stock to Wilport. They claimed that part of the purchase price had been given for the power to control the allocation of Newport's production, a power they claimed to be a "corporate asset" held in trust for the corporation by Feldmann as its fiduciary. The trial court ${ }^{9}$ denied recovery, holding that the "power to allocate the corporate product" was not a "corporate asset, but rather ... a direct attribute of management and an indirect attribute of a control block of stock." The court of appeals, with Judge Swan dissenting, reversed and remanded with instructions to the lower court to determine what part of the purchase price was paid for the power to allocate Newport's output. That part, the court ruled, Feldmann must share with the minority. If in so holding the court adopted the plaintiff's theory of the case-that the power to allocate output is a "corporate asset"-it has made a significant change in the law. Estimation of any change, however, is possible only against the background of the existing theories of restrictions on the right of a controlling shareholder to sell his interest.

\section{II}

The usual rule is that a controlling shareholder owes no duty to the minority shareholders when he sells his interest in a corporation. ${ }^{10}$ He may sell to

initiative in making the sale, this comment will refer to him as the controlling shareholder.

${ }^{5}$ Wilport's stockholders consisted of end-users of steel including the Maytag Washing Machine Co. and the Hudson Motor Car Co. Brief for Appellee at 5.

- Brief for Appellee at 2.

${ }^{7}$ Brief for Appellant at 5, citing Trial Court Finding 53 as follows: "The dominant motive of the purchasing group in seeking to purchase Feldmann's controlling stock interest in Newport was to obtain a continuing source of steel supply. Feldmann knew during the negotiations that such was their motive."

8 "Minority shareholders" is used in contradistinction to controlling shareholders. Here the minority shareholders as a matter of fact hold sixty-three per cent of the stock.

- Perlman v. Feldmann, D. Conn., Civil No. 3,086 (not reported), Judge Hincks presiding.

${ }^{10}$ Stanton v. Schenck, 140 N.Y. Misc. 621, 251 N.Y. Supp. 221 (S. Ct., 1931). See Insurance Agency Co. v. Blossom, 231 S.W. 636 (Mo. App., 1921); Roby v. Dunnett, 88 F. 2d 68 (C.A. 10th, 1937); Mayflower Hotel Stockholders Protective Committee v. 
whomever he pleases and exact whatever price he can get. This is so even though his purchaser is a customer of the corporation, either actual or potential. It makes no difference that he has been paid a premium for the control feature which his shares carry with them. ${ }^{11}$ The general rule has not, however, gone uncriticized. A. A. Berle, Jr., ${ }^{12}$ has long contended that control is an asset belonging to the corporation and that upon disposition by a shareholder of his controlling interest, the amount paid for the control feature should be shared with the minority shareholders. ${ }^{13}$ This argument, however, has not persuaded the courts. ${ }^{14}$

Restrictions have, however, been placed upon the freedom which the controlling shareholder ordinarily has in disposing of his stock. The cases embodying these restrictions can be grouped under two general headings, ${ }^{15}$ de-

Mayfiower Hotel Corp., 173 F. 2d 416 (App. D.C., 1949); Tryon v. Smith, 191 Ore. 172, 229 P. 2d 251 (1951).

${ }^{11}$ Stanton v. Schenck, 140 N.Y. Misc. 621, 251 N.Y. Supp. 221 (S. Ct., 1931) ; Tryon v. Smith, 191 Ore. 172,229 P. 2d 251. In the latter case the court stated: "[I]t is generally recognized that the stock of majority stockholders is of more value than that of the minority." Ibid., at 180 and 254.

12 Berle and Means, The Modern Corporation and Private Property 244 (1933).

${ }^{13}$ Patently, "control" is not an asset in the way a building or a tract of land is an asset. What Berle is arguing for is a distribution of the proceeds of the sale of a controlling stock interest among all the shareholders. He believes such a distribution is fair because "control belongs to all the shareholders." But does control belong to all the shareholders? A majority shareholder, through control of the board of directors, can determine what course of action the corporation takes; a minority shareholder cannot. In what sense, then, does control belong to the minority shareholder? Generally, none, for the shareholder who owns 51 per cent of the stock has almost complete control over the course of the corporate venture. Berle may feel compassion for the investor who has little or no say about what is done with his funds, but majority rule appears to be an inevitable concomitant of corporate action. As long as that rule prevails, control will belong-in the only meaningful sense of those words-to the majority. The majority, therefore, should be allowed to keep what it can get for selling control. If Berle's theory were adopted, minority shareholders would get something for nothing. Without giving up a single share, they would receive part of the proceeds the controlling shareholder obtains on selling his shares; and they would be in a position to repeat the procedure if the new controlling shareholder disposed of his interest, and so on, with each successive transfer of control.

Contrast the position of the controlling shareholder. Assume he paid $\$ 20$ per share for his controlling block of 51 per cent of the corporate shares, at a time when shares were selling over the market for $\$ 10$. He then sells his shares for $\$ 20$ a share when the market price is still $\$ 10$. Although he paid $\$ 20$ for his shares, Berle's rule will not allow him to recover that amount. Because of the difference between the market and the sale price, it will be concluded that $\$ 10$ was paid for control. This amount he must share with the minority: because they hold roughly 50 per cent of the stock, he will have to give them $\$ 5$ per share. There will be left, then, out of the price of $\$ 20$ per share, only $\$ 15$ for the seller. Certainly the prospects of such losses would discourage investors from buying controlling sharehold interests, and from selling such interests once obtained.

${ }^{11}$ See Restrictions on the Transfer of Controlling Stock, 40 Va. L. Rev. 195 (1954).

${ }^{15}$ Any such grouping is necessarily arbitrary. Dodd and Baker, in their casebook discussion of the problems arising on transfer of control [Cases and Materials on Corporations 570 ( $2 \mathrm{~d}$ ed., 1951)], state that the theories on which the minority shareholders 
pending upon the theory on which the restriction is based: (1) the "corporate transaction" cases ${ }^{16}$ and (2) the fraud and negligence cases. ${ }^{17}$

The corporate transaction cases are all founded on the proposition that the form of the transaction by which an outsider acquires a corporate asset should not affect the way in which the proceeds are divided among the shareholders. ${ }^{18}$ Commonvealth Title Insurance \& Trust Co. v. Seltzer ${ }^{10}$ exemplifies this line of cases. An outsider, desiring to purchase a corporation's sole asset, approached the corporation's president and offered to buy the asset. The president, instead of relaying the offer to the corporation, induced the outsider to purchase the controlling shares in the corporation from himself and a director. Once in a position of control, the outsider caused the corporation to sell him

are permitted to recover are "sometimes not clearly defined and [are] . . . interwoven." Ibid., at 572. Dodd and Baker group cases in the field under four general headings: (1) "corporate action" cases; (2) sale of "corporate office" cases; (3) misrepresentation cases; and (4) fraud and negligence cases. This comment selects from the Dodd and Baker classifications numbers (1) and (4). The misrepresentation cases are disregarded because the problems posed by them are no different from the problems posed by cases involving the sale of a non-controlling block of shares. Cases involving the sale of a corporate office are not considered because they are dependent on the corporate director relationship and not on the transfer of a controlling sharehold interest.

${ }^{16}$ Commonwealth Title Insurance \& Trust Co. v. Seltzer, 227 Pa. 410, 76 Atl. 77 (1910) ; Dunnett v. Arn, 71 F. 2d 912 (C.A. 10th, 1934); Roby v. Dunnett, 88 F. 2d 68 (C.A. 10th, 1937), cert. denied 301 U.S. 706 (1937); American Trust Co. v. California Western States Life Insurance Company, 15 Cal. 2d 42, 98 P. 2d 497 (1940).

${ }^{17}$ Insuranshares Corp. v. Northern Fiscal Corp., 35 F. Supp. 22 (E.D. Pa., 1940), measure of damages fixed 42 F. Supp. 126 (E.D. Pa., 1941); Gerdes v. Reynolds, 28 N.Y.S. 2d 622 (S. Ct., 1941) ; Levy v. Feinberg, 29 N.Y.S. 2d 550 (S. Ct., 1941), rev'd Levy v. American Beverage Corp., 265 App. Div. 208, 38 N.Y.S. 2d 517 (1st Dep't, 1942); Dale v. Thomas H. Temple Co., 186 Tenn. 69, 208 S.W. 2d 344 (1948).

${ }^{18}$ This is the analysis used by Dodd and Baker, op. cit. supra note 15 , at 572 ; attention is directed to the fact that a prospective purchaser who wishes to acquire control of the assets and business of a corporation has two basic ways of accomplishing his object: (1) He can buy the assets directly from the corporation, or (2) he can purchase a controlling interest in the corporation and then cause the corporation to convey the assets to himself. Frequently, when the second choice is made, the party who sells his stock to the purchaser realizes more on his shares than do the minority. However, any purchase by the first method would result in all shareholders getting equal treatment. Naturally, therefore, the minority shareholders contend that irrespective of the form of the transaction by which the purchaser acquires the asset, the shareholders of the corporation should share alike.

Dodd and Baker cite Commonwealth Title Insurance \& Trust Co. v. Seltzer, $227 \mathrm{~Pa}$. 410, 76 Atl. 77 (1910), discussed in the text infra, as the leading case in this field. But this case does not involve the mere election of an outsider to proceed by method (2) as opposed to method (1). Here the outsider approached the president and controlling shareholder and made an offer to purchase directly from the corporation. Nor does any other case cited by Dodd and Baker as falling in the corporate transaction line involve the mere election of the outsider to purchase one way instead of another; in each the controlling shareholder was aware that the outsider was interested in acquiring his stock so that the outsider could acquire the asset.

${ }^{20} 27$ Pa. 410, 76 Atl. 77 (1910). 
the asset at a price which was "not found to be inadequate." However, the amount which each minority shareholder received was less than he would have received if the corporation had initially been given the opportunity to sell its asset; and the amount that the president and his director associate received for selling their shares was more than they would have obtained in that event. Despite the absence of a finding that the price paid by the transferee for the asset was inadequate, the court in effect made such a finding by considering the profits of the two defendants as part of the price of the asset. In an action by certain minority shareholders for an accounting the court held that the stock transaction was in substance a sale by the corporation of its asset and that a part of the purchase price had been diverted by the defendants from the corporation to their own pockets. The court ordered the defendants to pay the minority shareholders pro rata the excess proceeds of the sale. ${ }^{20}$

The second group of cases involving restrictions on the controlling shareholder's right to sell his shares is based upon the presence of fraud or negligence $^{21}$ and is exemplified by Insuranshares Corp. v. Northern Fiscal Corp. ${ }^{22}$ There it was held that a controlling shareholder who sells his stock to one whom he knows or has reason to know is going to loot the corporation once he acquires control shall be liable to the corporation for the damages ${ }^{23}$ it suffers at the hands of the looter. The controlling shareholder in the Insuranshares case did not have actual knowledge that the party to whom he sold his stock would loot the corporation, but highly suspicious circumstances created a duty to investigate the integrity and financial responsibility of the purchaser; ${ }^{24}$ a duty the shareholder failed to discharge. The Berle thesis, plus these two lines of cases, represent the three theories on which Perlman v. Feldmann could have been decided.

${ }^{20}$ The court determined the measure of damages by adding the total amount received by the minority shareholders to what the controlling shareholders had received. This total was divided by the outstanding number of shares, and the amount so determined was taken as each shareholder's proper share. The controlling shareholders were required to contribute to the minority, to the extent that the minority did not receive this amount.

7 Cases cited note 17 supra.

${ }^{22} 35$ F. Supp. 22 (E.D. Pa., 1940), noted in 54 Harv. L. Rev. 648 (1941).

$\therefore$ The measure of damages was fixed in Insuranshares Corp. v. Northern Fiscal Corp., 42 F. Supp. 126 (E.D. Pa., 1941). The amount of damages is determined by the extent of the injury to the corporation and not by the size of the profits received by the shareholder who sells his controlling interest. As is pointed out in note, Duties of Controlling Shareholders in Transferring Their Shares, 54 Harv. L. Rev. 648, at 654 (1941), "this [rule] may result in tremendous liability." But the rule merely conforms to the standard damage doctrine applied in other tort cases. There is no reason why controlling shareholders should be exempt from the scope of that doctrine.

* The suspicious circumstances surrounding the sale were the inflated price paid for 'the shares, an agreement to convert part of the company's investment portfolio into cash before turning over control, and specific warnings of the dangers inherent in the sale. The court also stressed the fact that the investment company had only five years previously lost nearly 12 million dollars as the result of transfer of control to looters. 
III

A strong argument can be made that the case adopts a form of the Berle theory. At the outset of its opinion the court sets forth plaintiff's contention that "the consideration paid for the stock included compensation for the sale of a corporate asset, a power held in trust for the corporation by Feldmann as its fiduciary. This power was the ability to control the allocation of the corporate product in a time of short supply. . .."25 Transforming "the power to allocate a corporate product" into a "corporate asset," as plaintiffs urged the court to do, makes it difficult to envision a sale of a controlling block of stock in which the seller would not transfer a "corporate asset," since one of the powers which always goes with control is "allocation of the corporate product." Though this thesis does not equate "control" with "corporate asset" as does the Berle theory, it does transmute one of the powers that go to make up control into a "corporate asset," and thus reaches much the same result. ${ }^{26}$ The majority never expressly negates the possibility that it is deciding the case on the theory urged by the minority shareholders, and Judge Swan in his dissent attributes the language quoted to the majority as though it had adopted it as its own.

Yet the opinion does not appear to support such an interpretation. The majority never again refers to the power to allocate the company's product as a corporate asset; it prefers instead to talk in terms of Feldmann's fiduciary relationship to the corporation and of loss of "corporate opportunity"-the opportunity to exact a premium for its steel..$^{27}$ Moreover, the majority is at pains to point out that it does not adopt the theory that every time a controlling shareholder sells his shares, he must account to the minority shareholders for part of the proceeds. Rather the court indicates that the result in this instance was justified by the peculiar pricing situation confronting Newport.

It can be contended, moreover, that Perlman v. Feldmann falls within the fraud and negligence cases. In the Insuranshares case the controlling share-

${ }^{25}$ Perlman v. Feldmann, 219 F. 2d 173, 175 (C.A. 2d, 1955).

${ }^{28}$ The amount of the purchase price to be accounted for would depend upon whether the Berle theory or a modified version of it, which the Feldmann case can be interpreted to embody, was applied. Under the Berle theory, the court would determine the amount given for the power to control the corporation, and require that this amount be shared with the minority. Under the Feldmann case modification the court would determine what price was given for one specific power, the power to allocate the corporate product, and only that amount would have to be shared with the minority.

${ }^{2 \pi}$ An evidentiary problem arose at this point. There was no trial court finding that Newport would have been able to exact a premium in 1950 if Feldmann had not sold his stock. Whether such a finding would have been a necessary element in the plaintiff's case, the court does not consider. It solves the problem by stating that, because of Feldmann's fiduciary relationship to the corporation, the burden is on him to establish that there was no chance of obtaining a premium after 1950, the date of the sale. This burden would be hard to meet but does not seem inappropriate in the instant case, for the economic facts before the court indicated the great likelihood that such a premium could have been obtained. 
holders sold to a purchaser who they should have known would take a corporate asset for less than it was worth, that is, loot the investment portfolio. In the present case Feldmann had every reason to know that Wilport would take a corporate asset, Newport's steel, at a price less than Newport could obtain for it elsewhere. ${ }^{28}$

Though the court ignores such cases as Insuranshares in its preference for the conceptualization of "loss of corporate opportunity," the court's basic concern is the fact that Newport has been injured. This injury the court perceives lies in the fact that the parent corporation, Wilport, is forcing its subsidiary to sell steel to it at a price lower than Newport could otherwise obtain. The peculiar pricing policies of the industry may tend to conceal the injury, but the fact remains that the majority recognizes its presence.

Furthermore, Feldmann knew or had reason to know that the injury would occur once he sold to Wilport. The trial court record established that Feldmann knew that Wilport was purchasing his stock so that it would get a source of steel. And although Feldmann may not have had actual knowledge that Wilport intended to obtain the steel without payment of any premium, he should have suspected it, for the pricing situation literally invited a consumer-parent to take Newport's output at the mill list price without additional payment. The injury to Newport was the basis of the action, and that is the injury to be remedied.

Moreover, a close examination of the Seltzer case reveals that it is not significantly different from Insuranshares. Although the Seltzer court chose to dwell on the fact that the minority shareholders would have received more if the outsider had dealt directly with the corporation, the same elements present in Insuranshares are present in Seltzer: the controlling shareholder sold to a purchaser he knew would take a corporate asset for less than it was worth. ${ }^{29}$

To phrase the rule of liability in terms of "injury" and "knowledge" 30 has

${ }^{23}$ The fact that in the Feldmann case Wilport was paying part consideration for the asset, instead of taking it outright, should not obscure the fact that Wilport was taking Newport's steel for less than its market value.

${ }^{2}$ The controlling shareholder in the Seltzer case knew that the outsider was willing to pay the corporation a fixed price for the asset; he knew that upon payment of that price his interest in the corporation would entitle him to receive a certain amount, and that the minority shareholders would receive the rest of that purchase price. He knew or should have known that, if he could induce the outsider to prefer a method of dealing that would result in more being paid to him, it was inevitable that less would ultimately be paid to the minority shareholders. In short, he should have known that once the outsider acquired control of the corporation, he would cause the corporation to sell the asset to himself at a price which was below the price that he had originally offered.

${ }^{20}$ Judge Swan in his dissent in Perlman v. Feldmann states the rule as follows: If the controlling shareholder "knows or has reason to believe that the purchaser intends to exercise to the detriment of the corporation the power of management acquired by the purchase, such knowledge or reasonable suspicion will terminate the dominant shareholder's privilege to sell and will create a duty not to transfer the power of management to such purchaser. The duty seems to me to resemble the obligation which everyone is 
the desirable effect of directing the courts' attention to the significant elements in all these cases. Courts which de-emphasize the importance of these elements and concentrate instead on ambiguous concepts like "corporate transaction," as in the Seltzer case, and "corporate opportunity," as in the Feldmann case, increase the danger that subsequent courts will misconstrue the extent of a holding and either impose or refuse liability without regard for the former two elements.

Furthermore, the use of such concepts as "corporate transaction" and "corporate opportunity" will distract the courts from the proper measure of damages, which should not be the profit the controlling shareholder receives, but rather the extent of damage to the corporation. When emphasis is placed on the existence of the injury and the violation of a standard of care which led to it, the court will be induced to think of the tort measure of damages-compensation for the injury. It is highly appropriate that a controlling shareholder be required to rectify an injury he knowingly caused, and not merely be required to divest himself of profits he hoped to obtain from his wrong.

under not to assist another to commit a tort rather than the obligation of a fiduciary." Judge Swan did not find for the plaintiff because he believed the trial judge was correct in finding that Newport had not been injured.

\section{CORROBORATION OF ADMISSIONS}

A difficult burden is imposed on the prosecution when acts which are normally noncriminal constitute the external evidence of the crime, when a specific intent must be proved, and when the relevant facts are largely within the control of the defendant. In these situations the prosecution may be forced to rely heavily on extrajudicial statements ${ }^{1}$ of the accused, and courts may be tempted to relax rules of corroboration ${ }^{2}$ relating to admissions and confessions. $^{3}$

\footnotetext{
1 "Statements" is used herein to include admissions and confessions. Judicial statements are those made in open court. As to the boundaries of what constitutes a judicial statement, consult Proof of the Corpus Delicti Aliunde the Defendant's Confession, 103 U. of Pa. L. Rev. 638, 668 (1955).

${ }^{2}$ Corroboration as a requirement for sufficiency of proof applies only in criminal cases. A confession has no counterpart in civil cases. Extrajudicial admissions in criminal cases are treated significantly differently from extrajudicial admissions in civil cases. Both constitute sweeping exceptions to the hearsay rule, resting on the adversary theory of litigation. If the declarant is a party, he can "hardly object that he had no opportunity to cross examine himself or that he is unworthy of credence save when speaking under the sanction of oath." Morgan, Handbook of Evidence 231 (1954).

${ }^{3}$ A confession is an express acknowledgment of guilt, or an acknowledgment of all facts pertaining to a crime from which no other hypothesis can be supported except that of guilt. Admissions are acknowledgments of one or more facts consistent with a hypothesis of guilt, but which fall short of supplying all of the essential elements necessary to constitute the offense charged. 3 Wigmore, Evidence $\$ 821$, at 243 (3d ed., 1940). For a case discussing the distinction between an admission and a confession see People v. Fowler, 178 Cal. 657, 174 Pac. 892 (1918). See note 19 infra.
} 